\title{
Salinity and Supplemental Calcium Influence Growth of Rabbiteye and Southern Highbush Blueberry
}

\author{
Glenn C. Wright ${ }^{1}$ \\ Department of Horticultural Sciences, Texas A\&M University, College Station, TX 77843-2133
}

Kim D. Patten ${ }^{2}$

Texas A\&M University Agricultural Research and Extension Center at Overton, P.O. Drawer E, Overton, TX 75684

Malcolm C. Drew ${ }^{3}$

Department of Horticultural Sciences, Texas A\&M University, College Station, TX 77843-2133

Additional index words. mineral nutrition, salt stress, Vaccinium

\begin{abstract}
Tifblue' and 'Brightwell' rabbiteye blueberries (Vaccinium ashei Reade.) were subjected to 0,25, or 100 $\mathrm{mM} \mathrm{Na}^{+}$, as $\mathrm{Na}_{2} \mathrm{SO}_{4}$ or $\mathrm{NaCl}$, and $\mathrm{0}, 1,3$, or $10 \mathrm{mM}$ supplemental $\mathrm{Ca}^{2+}$, primarily as $\mathrm{CaSO}_{4}$, in an irrigated sand culture in the greenhouse. Additionally, the effect of $\mathrm{NaCl}$ on 'Sharpblue' southern highbush blueberry (primarily $V$. corymbosum L.) was examined. For unsalinized plants, fastest growth occurred in plants not receiving supplemental $\mathrm{Ca}^{2+}$. Root and shoot growth were depressed as salinity increased in plants lacking additional $\mathrm{Ca}^{2+}$. With $100 \mathrm{mM}$ $\mathrm{Na}^{+}$as $\mathrm{Na}_{2} \mathrm{SO}_{4}$. 'Tifblue' root and shoot dry weight increases were only $37 \%$ and $25 \%$, respectively, of the increase of unsalinized controls, while with $100 \mathrm{mM} \mathrm{Na}^{+}$as $\mathrm{NaCl}$, the corresponding shoot and root dry weight increases were only $38 \%$ and $43 \%$, respectively. 'Brightwell' plants reacted similarly to 'Tifblue' in salinity treatments with $\mathrm{Na}_{2} \mathrm{SO}_{4}$ and $\mathrm{NaCl}$, but 'Sharpblue' plants were more severely affected by $100 \mathrm{mM} \mathrm{NaCl}$ than were the rabbiteye cultivars. In no case did addition of $\mathrm{Ca}^{2+}$ have any ameliorative effect on either the dry weight of roots of plants exposed to 25 or $100 \mathrm{mM} \mathrm{NaCl}$ or on the shoot growth of plants exposed to $\mathrm{NaCl}$. The inability of $\mathrm{Ca}^{2+}$ to counter Cl- entry or toxicity may account for the lack of amelioration. In contrast, additional $\mathrm{Ca}^{2+}$ did improve shoot growth of plants exposed to $\mathrm{Na}_{2} \mathrm{SO}_{4}$. For 'Tifblue' plants supplied with $25 \mathrm{mM} \mathrm{Na}^{+}$as $\mathrm{Na}_{2} \mathrm{SO}_{4}$, growth increased by almost $25 \%$ in the presence of $10 \mathrm{mM} \mathrm{Ca}{ }^{2+}$, while for 'Tifblue' plants treated with $100 \mathrm{mM} \mathrm{Na}{ }^{+}$as $\mathrm{Na}_{2} \mathrm{SO}_{4}$, growth was more than three times greater in plants supplied with $1 \mathrm{mM}$ Ca than in those not given any $\mathrm{Ca}^{2+}$. Growth increase was primarily due to increased leaf area and number. Low $(1 \mathrm{mM})$ concentrations of $\mathrm{Ca}^{2+}$ were more effective in ameliorating the effects of $100 \mathrm{mM} \mathrm{Na}{ }^{+}$as $\mathrm{Na}_{2} \mathrm{SO}_{4}$ than were 3- and $10-\mathrm{mM} \mathrm{Ca}{ }^{2+}$ supplements, possibly because higher $\mathrm{Ca}^{2+}$ additions lead to metabolic damage in these calcifuge Vaccinium species.
\end{abstract}

Rabbiteye and southern highbush blueberries require good quality water to thrive and produce well. Many regions of the southeastern United States lack sufficient good quality water throughout the growing season. Saline ground water has emerged as a major difficulty limiting the expansion of the industry. Water $\mathrm{pH}<7.0$, total $\mathrm{Na}^{+}<2.0 \mathrm{mM}$, total $\mathrm{HCO}_{3}^{-}<1.5 \mathrm{~mm}$, and total $\mathrm{Cl}^{-}<4.0 \mathrm{~mm}$ are indicators of good quality water (Haby and Pennington, 1988). Although precipitation and surface water often meet these requirements and are preferred, these sources are often inadequate and lower quality water must be used for irrigation. Irrigation water in East Texas often exceeds $15 \mathrm{mM} \mathrm{Na}^{+}, 6 \mathrm{mM} \mathrm{Cl}^{-}$, and $10 \mathrm{mM} \mathrm{HCO}_{3}^{-}$(Texas Dept. of Health, 1990).

Haby et al. (1986) suggested that the deleterious effects of poor quality water $\left[\mathrm{pH}=8.7, \mathrm{EC}=0.695 \mathrm{dS} \cdot \mathrm{m}^{-1}\right.$, and so-

Received for publication 30 Dec. 1991. Accepted for publication 27 Apr. 1992. Contribution from the Texas Agricultural Experiment Station (Paper no. TA30342) and supported in part by the Expanded Research Area Fund of the Experiment Station. We thank Fincastle Nursery, La Rue, Texas, and Finch Nursery, BaiIcy, N.C., for the generous donation of the plants used in this study. The cost of publishing this paper was defrayed in part by the payment of page charges. Under postal regulations, this paper therefore must be hereby marked advertisement solely to indicate this fact.

'Assistant Research Scientist. Present address: Univ. of Arizona, Yuma Valley Agricultural Center, 6425 W. 8th St., Yuma, AZ 85364.

${ }^{2}$ Assistant Horticulturist. Present address: Washington State Univ.-Coastal Washington Research and Extension Unit, Route 1, Box 570 Pioneer Rd., Long Beach, WA 98631.

${ }^{3}$ Professor of Horticultural Sciences. dium adsorption ratio $(\mathrm{SAR})=29.71$ on rabbiteye blueberries were due to high levels of $\mathrm{Na}^{+}$. Furthermore, Patten et al. (1988) showed that $\mathrm{Na}^{+}$concentrations in the root zone may be two to four times higher than in the irrigation water, due to surface evaporation. Plants irrigated with such water exhibited significantly less growth than those irrigated with surface or rain water. Spiers (1983) noted that rabbiteye blueberries took up $\mathrm{Na}^{+}$rapidly, and that $\mathrm{Na}^{+}$was detrimental to their growth. We found no reports of the response of rabbiteye blueberry to other components of saline irrigation water, such as $\mathrm{Cl}-$, nor of the response of southern highbush blueberry to salinity.

The beneficial effect of supplemental $\mathrm{Ca}^{2+}$ on growth of saltstressed plants is widely recognized. LaHaye and Epstein (1969) showed that adequate $\mathrm{Ca}^{2+}$ was a requirement for shoot and root growth in salt-stressed bean (Phaseolus vulgaris L.). Similar results have been reported in shoots and/or roots of maize (Zea mays L.) (Cramer et al., 1988; Maas and Grieve, 1987). In bean and cotton (Gossypium hirsutum L.), adequate $\mathrm{Ca}^{2+}$ can exclude or limit $\mathrm{Na}^{+}$uptake into roots and $\mathrm{Na}^{+}$translocation from roots to shoots (Cramer et al., 1987; LaHaye and Epstein, 1971).

Vaccinium spp. including blueberries, are regarded as calcifuges, plants that have low leaf $\mathrm{Ca}^{2+}$ concentrations and thrive in soils low in $\mathrm{Ca}^{2+}$ (Hope-Simpson, 1938). However, the response of blueberries in the field to $\mathrm{Ca}^{2+}$ additions appears to be variable. Some research has indicated that high soil $\mathrm{Ca}^{2+}$ is associated with poor blueberry growth and vigor (Austin et al., 1986; Ballinger et al., 1958), while other work found that $\mathrm{Ca}^{2+}$ 
addition was not harmful (Spiers, 1979). The question therefore arises as to whether $\mathrm{Ca}^{2+}$ might offer any effective protection against salinity in a calcifuge species like blueberry.

The aim of our research was to determine the extent of $\mathrm{Na}^{+}$ and $\mathrm{Cl}$ - damage at particular external salt concentrations on the growth of rabbiteye and southern highbush blueberry. Sodium sulfate was applied with the assumption that th $\mathrm{SO}_{4}^{2-}$, which is known to be absorbed slowly by roots of higher plants (Marschner, 1986), is relatively noninjurious to blueberries. Since we found no indication of $\mathrm{SO}_{4}^{2-}$ toxicity to blueberries in the literature, any damage would be due to the specific effect of $\mathrm{Na}^{+}$. Comparison with experiments using $\mathrm{NaCl}$ would then provide an indication of the additional effect of $\mathrm{Cl}$-. A further objective was to evaluate the ability of supplemental $\mathrm{Ca}^{2+}$ to ameliorate salinity damage.

\section{Materials and Methods}

Sodium sulfate experiment. Dormant-potted 'Tifblue' and 'Brightwell' rabbiteye blueberries were received on 15 Mar. 1988. Shoots were pruned back to $40 \mathrm{~cm}$ to stimulate growth, flower buds were removed, and roots were rinsed with distilled water to remove as much peatmoss/shredded pine bark mulch potting medium as possible. Plants were transplanted into sterilized 5500-ml pots containing silica propping agent [man-made sand with a particle size between 0.635 and $1.270 \mathrm{~mm}$ (B.J. Titan, Bryan, Texas)] lined with fiberglass insulation (to prevent loss of medium) and placed in the greenhouse.

Plants were irrigated daily with $\approx 400 \mathrm{ml}$ of a complete nutrient solution consisting of (in $\mathrm{mM}$ ) $0.5\left(\mathrm{NH}_{4}\right)_{2} \mathrm{SO}_{4}, 0.1 \mathrm{KH}_{2} \mathrm{PO}_{4}$, $0.72 \mathrm{~K}_{2} \mathrm{SO}_{4}, 0.5 \mathrm{CaSO}_{4}, 0.65 \mathrm{MgSO}_{4}, 0.125 \mathrm{Fe}$ as ethylenediaminetetraacetic acid iron (III) monosodium salt, and (in $\mu \mathrm{M}$ ) $7.6 \times 10^{-3} \mathrm{ZnS} \mathrm{O}_{4}, 2.0 \times 10^{-2} \mathrm{Cu} \mathrm{SO}_{4}, 10.9 \mathrm{MnSO}_{4}, 1.2$ $\mathrm{H}_{3} \mathrm{BO}_{3}$ and $1.34 \times 10^{-1}\left(\mathrm{NH}_{4}\right)_{6} \mathrm{Mo}_{7} \mathrm{O}_{24}$. Solution was supplied automatically via trickle irrigation. When tensiometers indicated that the xylem water potential $\left(\psi^{\mathrm{w}}\right)$ of the medium was more negative than $-0.2 \mathrm{MPa}$, the irrigation rate was increased to $\approx 500 \mathrm{ml} \cdot \mathrm{day}^{-1}$. Plants were maintained with the complete nutrient solution for 60 days, until new shoot and root growth was extensive.

Six plants of each cultivar were destructively harvested before experimental treatments were applied, to measure initial plant weight. Shoot and root fresh weight of each plant was determined, and shoot and root dry weights were also recorded after drying at $60 \mathrm{C}$ for $48 \mathrm{~h}$. Dry weights for all six plants of each cultivar were pooled, and average shoot and root dry weight was determined. These data were later used in the calculation of the shoot and root dry weight increase over the duration of the experiment.

Experimental treatments on 144 plants, began on 15 May 1988 and consisted of 0,25 , or $100 \mathrm{mM} \mathrm{Na}^{+}(0,12.5$, or $50 \mathrm{~mm}$ $\mathrm{Na}_{2} \mathrm{SO}_{4}$ ) and $0,1,3$, or $10 \mathrm{~mm} \mathrm{Ca}{ }^{2+}$ applied with the remaining essential elements in the nutrient solution. Calcium and $\mathrm{Na}^{+}$ levels were crossed, forming 12 total treatments. Because of the low solubility of $\mathrm{CaSO}_{4}$, only $70 \%$ of each $\mathrm{Ca}^{2+}$ treatment was $\mathrm{CaSO}_{4}$, the remainder was made up of $20 \%$ from $\mathrm{Ca}\left(\mathrm{NO}_{3}\right)_{2}$ and $10 \%$ from $\mathrm{CaCl}_{2}$. All treatments contained equal amounts of $\mathrm{NO}_{3}^{-}, \mathrm{NH}_{4}^{+}$, and $\mathrm{K}^{+}$. Plants received $\approx 400$ or $500 \mathrm{ml}$ experimental solution daily as described; this was sufficient for some solution to drain from the containers. Solution $\mathrm{pH}$ and electrical conductivity (EC, corrected to 25C) were recorded when solutions were initially prepared and then again each time they were replenished. These values, along with solution composition and SAR are found in Table 1.
Plants were destructively harvested on 30 July 1988 following 76 days of treatment. Leaves and stems were separated from roots; and roots were rinsed with distilled water to remove as much silica as possible without causing damage, then were blotted dry. Root fresh weight was not determined because large amounts of silica remained within the root ball following washing (silica was easily removed following drying). Leaf and stem fresh weights for each plant were recorded, and a 20-leaf sample was removed at random from the total leaf mass of each plant. Fresh weight and total leaf area of the sample were determined, then the sample was reincorporated into the total leaf mass for the individual plant. Estimated total leaf count was calculated using the formula:

$$
\text { Est. total leaf count }=\frac{(\text { Sample leaf count }) \times(\text { Total leaf fresh weight })}{\text { Sample leaf fresh weight }}
$$

Plants were dried at $60 \mathrm{C}$ for $48 \mathrm{~h}$, then leaf, stem, and root dry weights were determined. Shoot : root ratio, leaf fresh weight : dry weight ratio, and specific leaf area (a measure of relative thickness) were also calculated.

The design was randomized complete block. Experiments involving 'Tifblue' and 'Brightwell' were $4\left(\mathrm{Ca}^{2+}\right.$ levels $) \times 3$ $\left(\mathrm{Na}^{+}\right.$levels) $\times 2$ (cultivars) factorial with six replications, for a total of 144 plants. Data were analyzed using the General Linear Model procedure (PROC GLM) of the Statistical Analysis Service software package (SAS Inc., Cary, N.C.).

Sodium chloride experiment. Dormant, bare-root 'Tifblue' and 'Brightwell' rabbiteye blueberries and 'Sharpblue' southern highbush blueberries were planted on 15 Mar. 1989. The rabbiteye blueberries were handled in the same manner as in 1988, while the 'Sharpblue' plants were transplanted into sterilized 2750-ml pots containing the fiberglass insulation and silica propping agent as described above. 'Sharpblue' plants were pruned to a height of $20 \mathrm{~cm}$. The irrigation regime was the same as that of 1988.

Six 'Tifblue' and six 'Brightwell' plants were again removed in 1989, before treatment. Leaf, stem, and root fresh and dry weights were measured and estimated total leaf count was determined as in 1988. Insufficient plant material prevented pretreatment sampling of 'Sharpblue'.

Plants were maintained with the complete nutrient solution until 15 May 1989, when treatments commenced. All plants received 0,25 , or $100 \mathrm{~mm} \mathrm{NaCl}$, rather than $\mathrm{Na}_{2} \mathrm{SO}_{4}$, as the $\mathrm{Na}^{+}$source, but otherwise the compositions of the 12 nutrient solutions were the same as those of 1988 (Table 1). Solution $\mathrm{pH}$ and EC were again measured when the solutions were made and replenished. 'Sharpblue' plants were only treated with those solutions containing 0 or $10 \mathrm{mM} \mathrm{Ca}^{2+}$ because insufficient plants were available to test all $\mathrm{Ca}^{2+}$ levels. Plants were destructively harvested on 17 July 1989, following 63 days of treatment. Harvest protocol was the same as that of the 1988 experiment.

The design and data analysis were the same as described above. The experiment involving 'Sharpblue' was a $2 \times 3$ factorial with four replications, for a total of 24 plants.

\section{Results}

The blueberry cultivars responded differently to salinization with $\mathrm{Na}_{2} \mathrm{SO}_{4}$ and $\mathrm{NaCl}$. Furthermore, each cultivar performed differently with salinization, so that data could not be averaged over all cultivars. The principal effects of salinity on growth are described below (Tables 2-5), and interactions between salt concentration and $\mathrm{Ca}^{2+}$ are given graphically (Figs. 1 and 2). 
Table 1. Composition, sodium adsorption ratio (SAR), $\mathrm{pH}$, and electrical conductivity of nutrient solutions for blueberries.'

\begin{tabular}{|c|c|c|c|c|c|c|c|c|c|c|c|c|}
\hline \multirow{2}{*}{$\begin{array}{l}\text { Total } \\
\mathrm{Na}^{+\mathrm{y}} \\
(\mathrm{mM})\end{array}$} & \multirow{2}{*}{$\begin{array}{l}\text { Total } \\
\mathrm{Ca}^{2+} \\
(\mathrm{mM})\end{array}$} & \multirow{2}{*}{$\begin{array}{c}\mathrm{CaSO}_{4} \\
(\mathrm{mM})\end{array}$} & \multirow{2}{*}{$\begin{array}{c}\mathrm{Ca}\left(\mathrm{NO}_{3}\right)_{2} \\
(\mathrm{mM})\end{array}$} & \multirow{2}{*}{$\begin{array}{l}\mathrm{CaCl}_{2} \\
(\mathrm{mM})\end{array}$} & \multirow{2}{*}{$\begin{array}{l}\mathrm{KNO}_{3} \\
(\mathrm{mM})\end{array}$} & \multirow{2}{*}{$\begin{array}{c}\left(\mathrm{NH}_{4}\right)_{2} \mathrm{SO}_{4} \\
(\mathrm{mM})\end{array}$} & \multirow{2}{*}{$\begin{array}{c}\mathrm{K}_{2} \mathrm{SO}_{4} \\
(\mathrm{mM})\end{array}$} & \multirow[b]{2}{*}{ SAR } & \multicolumn{2}{|c|}{$\mathrm{pH}^{\mathrm{x}}$} & \multicolumn{2}{|c|}{$\begin{array}{c}E C \\
\left(\mathrm{~d} S \cdot \mathrm{m}^{-1}\right)\end{array}$} \\
\hline & & & & & & & & & $\mathrm{Na}_{2} \mathrm{SO}_{4}$ & $\mathrm{NaCl}$ & $\mathrm{Na}_{2} \mathrm{SO}_{4}$ & $\mathrm{NaCl}$ \\
\hline 0 & 0 & 0.0 & 0.0 & 0.0 & 4.0 & 4.0 & 0.0 & 0.0 & 6.1 & 5.4 & 1.22 & 1.18 \\
\hline 0 & 1 & 0.7 & 0.2 & 0.1 & 3.6 & 4.0 & 0.4 & 0.0 & 5.4 & 5.3 & 1.30 & 1.38 \\
\hline 0 & 3 & 2.1 & 0.6 & 0.3 & 2.8 & 4.0 & 1.2 & 0.0 & 5.2 & 5.0 & 1.62 & 1.81 \\
\hline 0 & 10 & 7.0 & 2.0 & 1.0 & 0.0 & 4.0 & 4.0 & 0.0 & 5.1 & 5.1 & 2.37 & 2.49 \\
\hline 25 & 0 & 0.0 & 0.0 & 0.0 & 4.0 & 4.0 & 0.0 & 31.0 & 5.5 & 6.4 & 3.23 & 3.80 \\
\hline 25 & 1 & 0.7 & 0.2 & 0.1 & 3.6 & 4.0 & 0.4 & 19.4 & 5.6 & 5.0 & 3.34 & 3.75 \\
\hline 25 & 3 & 2.1 & 0.6 & 0.3 & 2.8 & 4.0 & 1.2 & 13.0 & 6.1 & 5.1 & 3.72 & 3.80 \\
\hline 25 & 10 & 7.0 & 2.0 & 1.0 & 0.0 & 4.0 & 4.0 & 7.6 & 6.0 & 4.9 & 4.00 & 4.53 \\
\hline 100 & 0 & 0.0 & 0.0 & 0.0 & 4.0 & 4.0 & 0.0 & 124.0 & 6.7 & 5.3 & 8.87 & 8.80 \\
\hline 100 & 1 & 0.7 & 0.2 & 0.1 & 3.6 & 4.0 & 0.4 & 77.8 & 6.0 & 5.4 & 8.08 & 9.35 \\
\hline 100 & 3 & 2.1 & 0.6 & 0.3 & 2.8 & 4.0 & 1.2 & 52.3 & 6.2 & 5.0 & 8.92 & 9.55 \\
\hline 100 & 10 & 7.0 & 2.0 & 1.0 & 0.0 & 4.0 & 4.0 & 30.6 & 5.9 & 5.1 & 8.72 & 8.48 \\
\hline
\end{tabular}

${ }^{2}$ Additionally, solutions contained $0.1 \mathrm{mM} \mathrm{K} \mathrm{H}_{2} \mathrm{P} \mathrm{O}_{4}, 0.65 \mathrm{~mm} \mathrm{Mg} \mathrm{S} \mathrm{O}, 0.125 \mathrm{~mm}$

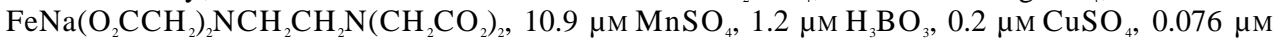
$\mathrm{ZnSO}_{4}$, and $15 \mu \mathrm{M}\left(\mathrm{NH}_{4}\right)_{6} \mathrm{Mo}_{7} \mathrm{O}_{24}$.

Total $\mathrm{Na}^{+}$as $\mathrm{Na}_{2} \mathrm{SO}_{4}$ or as $\mathrm{NaCl}$.

${ }^{\mathrm{x}} \mathrm{pH}$ and $\mathrm{EC}$ values are means of at least three three replications.

Sodium sulfate experiment. Dry weight increase of roots and shoots of both blueberry cultivars decreased linearly as $\mathrm{Na}^{+}$ concentration in the nutrient solution increased (Table 2), although only a small inhibition was found at $25 \mathrm{~mm} \mathrm{Na}^{+}$. For 'Tifblue' plants, shoot and root dry weight increase of plants subject to $100 \mathrm{~mm} \mathrm{Na}^{+}$was only $37 \%$ and $25 \%$, respectively, of the increase of unsalinized controls. The $\mathrm{Na}^{+}$effect on 'Brightwell' was more severe. Dry weight increase of 'Brightwell' shoots and roots of plants treated with $100 \mathrm{~mm} \mathrm{Na}^{+}$was only $18 \%$ and $15 \%$, respectively, of the increase of unsalinized controls.

The $\mathrm{Ca}^{2+}$ treatments had no significant main effect on the dry weight increase of 'Tifblue' shoots, but an interaction between the $\mathrm{Ca}^{2+}$ and $\mathrm{Na}_{2} \mathrm{SO}_{4}$ treatment effects was significant at $P=0.07$ (Fig. 1A). The greatest shoot dry weight increase was with controls receiving no additional $\mathrm{Ca}^{2+}$. For plants treated with $25 \mathrm{mM} \mathrm{Na}^{+}$, those receiving $10 \mathrm{mM} \mathrm{Ca}^{2+}$ additions grew almost $25 \%$ more than those not supplied with additional $\mathrm{Ca}^{2+}$. For plants treated with $100 \mathrm{~mm} \mathrm{Na}^{+}$, those that received $1 \mathrm{~mm}$ $\mathrm{Ca}^{2+}$ produced more than three times more growth than plants not receiving $\mathrm{Ca}^{2+}$. Salinity was most detrimental to dry weight increase when there was no supplemental $\mathrm{Ca}^{2+}$ (Fig. 1A).

Calcium treatments affected growth of 'Brightwell' shoots, being significant at close to $P=0.10$, but there was no sig-

Table 2. Effect of $\mathrm{Na}_{2} \mathrm{SO}_{4}$ or $\mathrm{NaCl}$ and $\mathrm{Ca}^{2+}$ treatments on dry weight increase of rabbiteye blueberry plants.

\begin{tabular}{|c|c|c|c|c|c|c|c|c|}
\hline \multirow{4}{*}{$\begin{array}{l}\text { Ion and } \\
\text { concn } \\
(\mathrm{mM})\end{array}$} & \multicolumn{8}{|c|}{ Dry wt increase ( $\mathrm{g} / \mathrm{plant}$ ) } \\
\hline & \multicolumn{4}{|c|}{$1988 \mathrm{Na}_{2} \mathrm{SO}_{4}$ study } & \multicolumn{4}{|c|}{$1989 \mathrm{NaCl}$ study } \\
\hline & \multicolumn{2}{|c|}{ Tifblue } & \multicolumn{2}{|c|}{ Brightwell } & \multicolumn{2}{|c|}{ Tifblue } & \multicolumn{2}{|c|}{ Brightwell } \\
\hline & Shoots $^{z}$ & Roots $^{y}$ & Shoots & Roots & Shoots & Roots & Shoots & Roots \\
\hline \multicolumn{9}{|l|}{$\mathrm{Na}+$} \\
\hline 0 & 59.1 & 17.9 & 48.5 & 17.8 & 44.4 & 12.9 & 50.0 & 18.2 \\
\hline 25 & 55.3 & 16.5 & 41.7 & 16.0 & 40.5 & 13.1 & 39.3 & 15.0 \\
\hline 100 & 21.7 & 4.5 & 8.6 & 2.6 & 17.1 & 5.5 & 22.0 & 7.5 \\
\hline \multicolumn{9}{|l|}{$\mathrm{Ca}^{2+}$} \\
\hline 0 & 41.7 & 12.5 & 26.8 & 9.0 & 36.2 & 11.1 & 37.5 & 13.6 \\
\hline 1 & 50.0 & 14.3 & 34.5 & 12.9 & 33.5 & 9.0 & 39.2 & 14.3 \\
\hline 3 & 39.0 & 9.0 & 35.4 & 12.9 & 32.8 & 10.7 & 38.2 & 15.4 \\
\hline 10 & 47.2 & 14.7 & 34.0 & 13.4 & 33.1 & 10.8 & 33.2 & 11.5 \\
\hline \multicolumn{9}{|l|}{ Source $^{x}$} \\
\hline $\mathrm{Na}^{+}$ & 0.0001 & 0.0001 & 0.0001 & 0.0001 & 0.0001 & 0.0001 & 0.0001 & 0.0001 \\
\hline $\mathrm{Ca}^{2+}$ & NS & NS & 0.1036 & NS & NS & NS & NS & NS \\
\hline $\mathrm{Ca}^{2}+\times \mathrm{Na}^{+}$ & 0.0639 & NS & NS & NS & NS & NS & NS & NS \\
\hline \multicolumn{9}{|c|}{ Contrast ${ }^{w}$} \\
\hline Linear $\mathrm{Na}^{+}$ & 0.0001 & 0.0001 & 0.0001 & 0.0001 & 0.0001 & 0.0001 & 0.0001 & 0.0001 \\
\hline
\end{tabular}

${ }^{2}$ Shoot dry weight increase $=[($ leaf dry weight + stem dry weight $)-$ shoot dry weight before treatment initiation].

${ }^{y}$ Root dry weight increase $=$ [root dry weight - root dry weight before treatment initiation].

${ }^{x}$ Probability of significant $\mathrm{F}$ value, NS = nonsignificant.

"Both linear and quadratic $\mathrm{Ca}^{2+}$ contrasts were nonsignificant. 


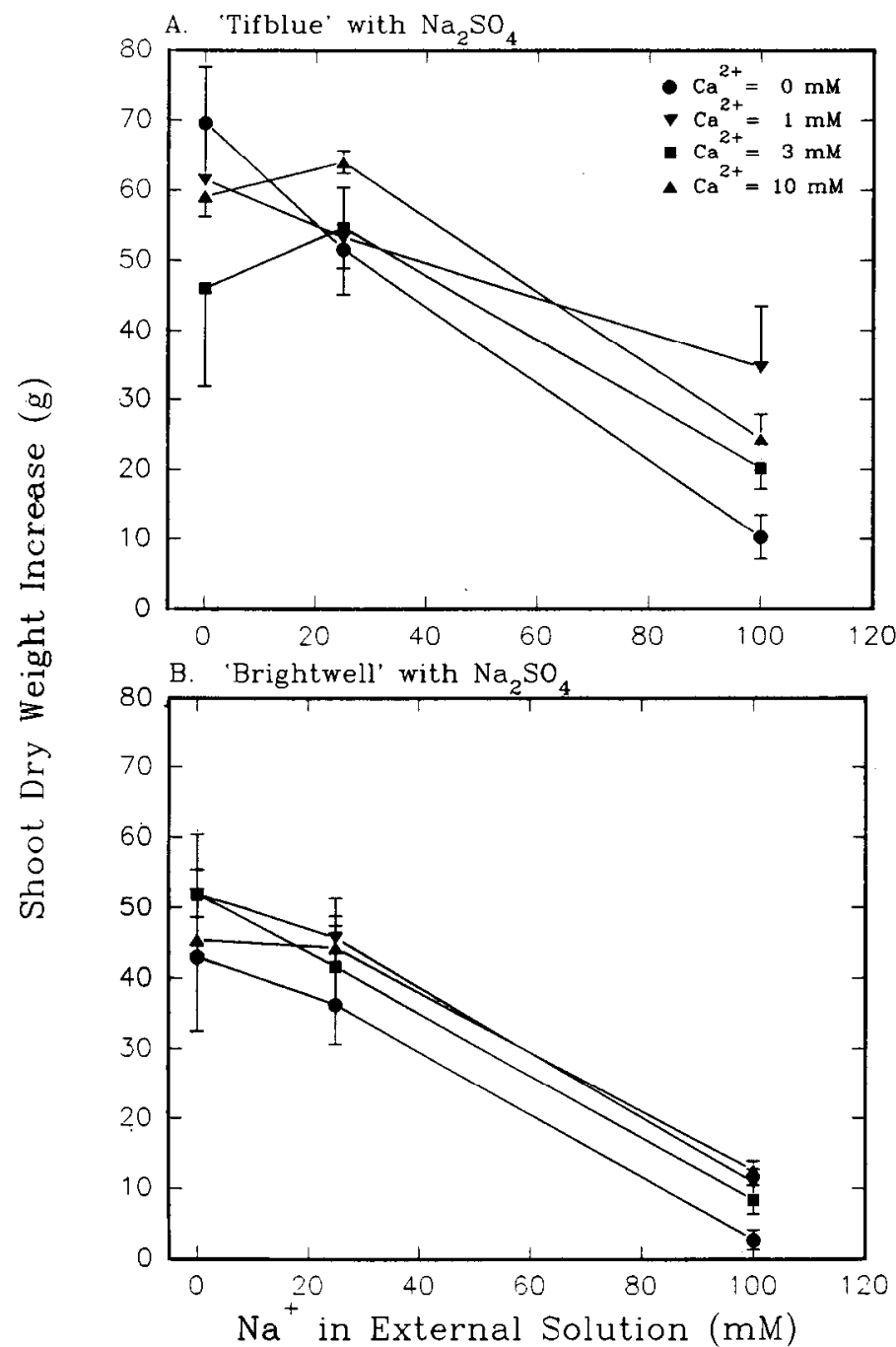

Fig. 1. Shoot dry weight increase of 'Tifblue' (A) and 'Brightwell' (B) rabbiteye blueberries treated with $\mathrm{Na}_{2} \mathrm{SO}_{4}$ and $\mathrm{Ca}^{2+}$. Vertical bars indicate SE.

nificant $\mathrm{Ca}^{2+} \times \mathrm{Na}_{2} \mathrm{SO}_{4}$ interaction (Fig 1B). Plants receiving no $\mathrm{Ca}^{2+}$ supplement grew the least, regardless of the level of $\mathrm{Na}^{+}$supplied. For 'Brightwell' plants, $1 \mathrm{~mm} \mathrm{Ca}^{2+}$ was no more effective in alleviating $\mathrm{Na}^{+}$inhibition of growth than lack of $\mathrm{Ca}^{2+}$ in the solution or higher concentrations.

Calcium treatments had no significant effects on the dry weight increase of 'Tifblue' or 'Brightwell' roots (Table 2).

All measured growth characteristics of 'Tifblue', except the shoot : root ratio, declined linearly in response to increased $\mathrm{Na}^{+}$ levels (Table 3). Specific leaf area was not affected by $\mathrm{Ca}^{2+}$ or $\mathrm{Na}^{+}$treatments (data not shown). Leaf and stem fresh weight, dry weight of leaf, stem, and root, and estimated leaf count declined slightly in plants supplied with $25 \mathrm{~mm} \mathrm{Na}^{+}$compared with unsalinized controls, and an appreciably greater reduction took place at $100 \mathrm{mM} \mathrm{Na}{ }^{+}$(Table 3).

The $\mathrm{Na}^{+} \times \mathrm{Ca}^{2+}$ interaction had a significant effect on leaf dry weight (Fig. 2) and leaf area (data not shown). For unsalinized plants, leaf dry weight at the end of the experiment was highest without supplementary $\mathrm{Ca}^{2+}$. However, for salinized plants, both attributes showed a distinct response to supplementary $\mathrm{Ca}^{2+}$, particularly with $1 \mathrm{mM} \mathrm{Ca}^{2+}$ and $100 \mathrm{~mm} \mathrm{Na}^{+}$, when leaf dry weight was more than three times higher and leaf area was $\approx 50 \%$ higher, both compared with the $0 \mathrm{mM} \mathrm{Ca}^{2+}$ treat- ments. Estimated leaf count was highest in plants treated with $1 \mathrm{mM} \mathrm{Ca}^{2+}$ (Table 3). A gray leaf necrosis appeared on older leaves of some plants treated with $100 \mathrm{~mm} \mathrm{Na}^{+}$and was more extensive on plants not supplied with $\mathrm{Ca}^{2+}$. The lower leaf fresh weight : dry weight ratio of plants subject to $100 \mathrm{mM} \mathrm{Na}^{+}$was at least partially because of the tissue necrosis. 'Tifblue' stem fresh and dry weights and root dry weight were not affected by $\mathrm{Ca}^{2+}$ treatment.

'Brightwell' plants responded to $\mathrm{Na}_{2} \mathrm{SO}_{4}$ salinity in essentially the same way as did 'Tifblue' plants (data not shown). Specific leaf area was not affected by $\mathrm{Na}^{+}$or $\mathrm{Ca}^{2+}$ treatments. There were decreases in leaf and stem fresh weights, leaf stem and root dry weights, estimated leaf count, leaf fresh weight : dry weight ratio, shoot : root ratio and average leaf area with increasing $\mathrm{Na}^{+}$concentrations in the external solution. 'Brightwell' plants treated with any concentration of $\mathrm{Ca}^{2+}$ showed improved leaf fresh weight, dry weight, and estimated leaf count. Like 'Tifblue', when 'Brightwell' plants were subjected to 25 and $100 \mathrm{~mm} \mathrm{Na}$, supplemental $\mathrm{Ca}^{2+}$ led to a larger average leaf area than in those not supplied with $\mathrm{Ca}^{2}+$ (data not shown).

Sodium chloride experiment. The $\mathrm{Ca}^{2+} \times \mathrm{Na}^{+}$interaction effect on shoot and root dry weight increase was not significant, but shoot and root dry weight increase was slowed as $\mathrm{Na}^{+}$ increased in the external solution (Table 2), and the relationship between dry weight increase and external $\mathrm{Na}^{+}$concentration was linear. For 'Tifblue' plants, shoot and root dry weight increase of plants subject to $100 \mathrm{~mm} \mathrm{NaCl}$ was only $38 \%$ and $43 \%$, respectively, of the increase of unsalinized controls.

The inhibitory effect of $\mathrm{Na}^{+}$on dry weight increase of 'Brightwell' was similar to the effect on 'Tifblue'. Dry weight increase of 'Brightwell' shoots and roots exposed to $100 \mathrm{~mm} \mathrm{Na}^{+}$was $44 \%$ and $42 \%$, respectively, of the dry weight increase of the controls.

Calcium treatments had no significant influence on the dry weight increase of 'Tifblue' or 'Brightwell' shoots and roots exposed to $\mathrm{Na}^{+}$.

All 'Tifblue' growth measurements decreased linearly as $\mathrm{Na}^{+}$ increased in the external solution (Table 4). Treatment with 1 $\mathrm{mM} \mathrm{Ca}^{2+}$ led to increased leaf fresh weight : dry weight and shoot : root ratios and to larger average leaf area. A tan leaf necrosis that appeared on plants provided $100 \mathrm{mM} \mathrm{Na}^{+}$as $\mathrm{NaCl}$ was more extensive than on plants treated with $100 \mathrm{mM} \mathrm{Na}^{+}$as $\mathrm{Na}_{2} \mathrm{SO}_{4}$. Calcium treatments had no significant influence on the other growth parameters.

For 'Brightwell' plants, growth was also retarded by $\mathrm{Na}+$ in the external solution: leaf and stem fresh weight, estimated leaf count, leaf, stem, and root dry weight, leaf fresh weight : dry weight ratio, shoot : root ratio, and average leaf area all decreased (data not shown), and a negative linear relationship was found between each characteristic and $\mathrm{Na}^{+}$concentration. Calcium treatments had no influence on growth characteristics, nor were there any significant $\mathrm{Ca}^{2+} \times \mathrm{Na}^{+}$interactions. Tan leaf necrosis also appeared on $100 \mathrm{~mm} \mathrm{Na}$-treated plants.

For 'Sharpblue' plants, increasing $\mathrm{Na}^{+}$concentrations in the external solution caused decreases in all characteristics measured (Table 5). Estimated leaf count of plants given $100 \mathrm{~mm}$ $\mathrm{Na}^{+}$was less than half the leaf count of those plants not under $\mathrm{Na}^{+}$treatment. Leaf dry weight and leaf area of the $100 \mathrm{~mm}$ $\mathrm{NaCl}$-salinized plants were only $21 \%$ and $29 \%$, respectively, of leaf dry weight and leaf area of the nontreated plants, and root dry weight of the $100-\mathrm{mm}$ plants was only $26 \%$ of the control plants. Tan leaf necrosis appeared on some plants treated with $25 \mathrm{~mm} \mathrm{Na}^{+}$, and was more severe on plants supplied with 100 
Table 3. Influence of $\mathrm{Na}_{2} \mathrm{SO}_{4}$ and $\mathrm{Ca}^{2+}$ treatments on growth parameters of 'Tifblue' rabbiteye blueberry plants.

\begin{tabular}{|c|c|c|c|c|c|c|c|c|c|}
\hline \multirow{2}{*}{$\begin{array}{l}\text { Ion and } \\
\text { concn } \\
(\mathrm{mM}) \\
\end{array}$} & \multicolumn{2}{|c|}{ Fresh $w^{z}{ }^{z}(g)$} & \multirow{2}{*}{$\begin{array}{c}\text { Estimated } \\
\text { leaf } \\
\text { count }\end{array}$} & \multicolumn{3}{|c|}{ Dry wt $(\mathrm{g})$} & \multirow{2}{*}{$\begin{array}{c}\text { Leaf } \\
\text { fresh wt } \\
\text { dry wt } \\
\text { ratio } \\
\end{array}$} & \multirow{2}{*}{$\begin{array}{l}\text { Shoot : } \\
\text { root } \\
\text { ratio }\end{array}$} & \multirow{2}{*}{$\begin{array}{l}\text { Avg } \\
\text { leaf } \\
\text { area } \\
\left(\mathrm{cm}^{2}\right)\end{array}$} \\
\hline & Leaf & Stem & & Leaf & Stem & Root & & & \\
\hline \multicolumn{10}{|l|}{$\mathrm{Na}^{+}\left(\mathrm{Na}_{2} \mathrm{SO}_{4}\right)$} \\
\hline 0 & 112.3 & 63.7 & 319 & 41.1 & 24.0 & 23.8 & 2.7 & 3.0 & 12.7 \\
\hline 25 & 106.7 & 60.7 & 300 & 38.3 & 22.9 & 22.4 & 2.8 & 2.9 & 12.9 \\
\hline 100 & 39.4 & 26.1 & 136 & 16.6 & 11.2 & 10.4 & 2.3 & 2.9 & 9.8 \\
\hline \multicolumn{10}{|l|}{$\mathrm{Ca}^{2+}$} \\
\hline 0 & 76.8 & 46.0 & 216 & 29.3 & 18.3 & 18.4 & 2.5 & 2.6 & 10.8 \\
\hline 1 & 97.4 & 54.6 & 284 & 35.3 & 20.6 & 20.2 & 2.7 & 3.0 & 12.6 \\
\hline 3 & 78.5 & 43.0 & 241 & 28.5 & 16.5 & 14.9 & 2.7 & 3.2 & 11.4 \\
\hline 10 & 84.6 & 53.3 & 246 & 32.5 & 20.7 & 20.6 & 2.6 & 2.9 & 12.1 \\
\hline \multicolumn{10}{|l|}{ Source } \\
\hline $\mathrm{Na}^{+}$ & 0.0001 & 0.0001 & 0.0001 & 0.0001 & 0.0001 & 0.0001 & 0.0001 & NS & 0.0001 \\
\hline $\mathrm{Ca}^{2+}$ & 0.0893 & NS & 0.0868 & NS & NS & NS & 0.0001 & NS & 0.0437 \\
\hline$\underset{\text { Contrast }^{\mathrm{x}}}{\mathrm{Ca}^{2+}+\times \mathrm{Na}_{2} \mathrm{SO}_{4}}$ & 0.0889 & NS & NS & 0.0528 & NS & NS & 0.0228 & NS & 0.0006 \\
\hline Linear $\mathrm{Na}^{+}$ & 0.0001 & 0.0001 & 0.0001 & 0.0001 & 0.0001 & 0.0001 & 0.0001 & & 0.0001 \\
\hline Quadratic $\mathrm{Ca}^{2+}$ & NS & NS & NS & NS & NS & 0.1029 & 0.0005 & 0.0371 & NS \\
\hline
\end{tabular}

${ }^{2}$ All fresh and dry weight values are reported as grams per plant.

'Probability of a significant $\mathrm{F}$ value, NS = nonsignificant.

${ }^{x}$ Linear $\mathrm{Ca}^{2+}$ contrasts were nonsignificant.

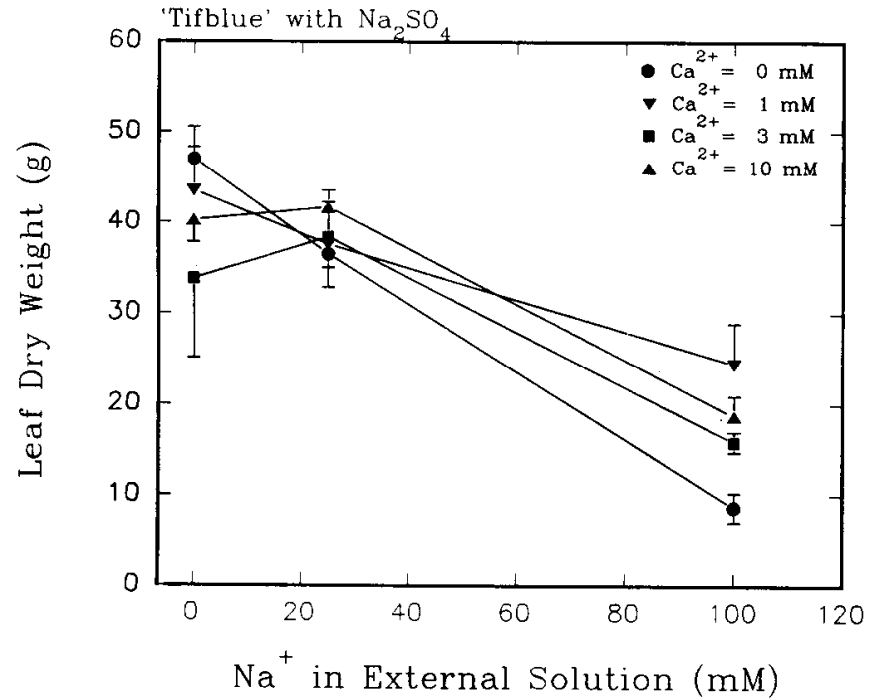

Fig. 2. Leaf dry weight of 'Tifblue' rabbiteye blueberries treated with $\mathrm{Na}_{2} \mathrm{SO}_{4}$ and $\mathrm{Ca}^{2+}$. Vertical bars indicate SE.

$\mathrm{mM} \mathrm{Na} \mathrm{Na}^{+}$. One-third of these plants died. Calcium treatments had no ameliorative effect on salinity damage to 'Sharpblue' plants.

\section{Discussion}

Salinization with $\mathrm{Na}_{2} \mathrm{SO}_{4}$ or $\mathrm{NaCl}$ retarded vegetative growth of 'Tifblue', 'Brightwell', and 'Sharpblue' blueberries, although plants appeared to tolerate the lower concentration (25 vs. $100 \mathrm{~mm} \mathrm{Na}$ ). Supplemental $\mathrm{Ca}^{2+}$ appeared to offset salinity damage to shoots when plants were treated with $\mathrm{Na}^{+}$as $\mathrm{Na}_{2} \mathrm{SO}_{4}$, but not with $\mathrm{Na}^{+}$as $\mathrm{NaCl}$.

Sodium or $\mathrm{NaCl}$ application depressed root growth. Root growth was not improved by $\mathrm{Ca}$ treatments, regardless of $\mathrm{Na}^{+}$concentration, a result that contrasts with studies indicating $\mathrm{Ca}^{2+}$ amelioration of $\mathrm{NaCl}$ inhibited root growth, using comparable concentrations of $\mathrm{Na}^{+}$, in species as diverse as cotton (Cramer et al., 1987) barley (Hordeum vulgare L.) (Cramer et al., 1989), and bean (LaHaye and Epstein, 1971).
Effects of the higher concentration of $\mathrm{Na}^{+}$as $\mathrm{NaCl}$ on growth were more severe than the effects of the higher concentration of $\mathrm{Na}_{2} \mathrm{SO}_{4}$ at equimolar concentrations of $\mathrm{Na}^{+}$. The inhibition of growth reported in our experiments, $\approx 50 \%$ for 'Tifblue' plants at $100 \mathrm{~mm} \mathrm{Na}^{+}$as $\mathrm{NaCl}$ is greater than the $33 \%$ decrease in dry weight of 'Tifblue' in sand culture, under high salinity, reported by Spiers (1983). In Spiers' experiment, the highest salt concentration used was only $\approx 1 / 20$ th $(5.21 \mathrm{mM} \mathrm{NaCl})$ of the highest level used in this experiment, but the experiment lasted almost 16 months.

Growth reduction was often followed by leaf necrosis, beginning at the tip and margins, then advancing basipetally. Ehlig (1965) noted severe necrosis on Rubus spp. treated with $\mathrm{NaCl}$ and attributed injury primarily to $\mathrm{Cl}^{-}$because $\mathrm{Cl}^{-}$accumulated in the shoots faster than $\mathrm{Na}^{+}$. Similarly, $\mathrm{Cl}^{-}$damage was judged to be more severe than $\mathrm{Na}^{+}$damage in diverse other species (Bongi and Loreto, 1989; Downton, 1977; Manchanda and Sharma, 1989). Ballinger (1962) found that $104 \mathrm{~mm} \mathrm{Cl}^{-}$produced only limited foliar tip yellowing and occasional browning in highbush blueberry. But in our case, it is likely that $\mathrm{Cl}^{-}$was more damaging to rabbiteye and southern highbush blueberry shoots than was $\mathrm{Na}^{+}$, because leaf necrosis was more severe on $\mathrm{NaCl}$-treated plants than on plants supplied with $\mathrm{Na}^{+}$as $\mathrm{Na}_{2} \mathrm{SO}_{4}$.

Other studies indicate that the detrimental effects of $\mathrm{NaCl}$ on plants may be overcome, at least in part, by $\mathrm{CaSO}_{4}$ application. LaHaye and Epstein (1971) found with brittle wax bean that dry weights of stem and leaves of $\mathrm{NaCl}$-stressed plants increased as the $\mathrm{CaSO}_{4}$ concentration of the solution was raised from 1 to $10 \mathrm{~mm}$. Similar results have been reported on Leucaena leucocephala (Hansen and Munns, 1988), and sour orange (Citrus aurantium L.) (Zekri and Parsons, 1990). The presence of $\mathrm{Ca}^{2+}$ is necessary to maintain $\mathrm{K}^{+} / \mathrm{Na}^{+}$selectivity, to maintain the $\mathrm{Ca}^{2+}$ status of developing leaves, and to prevent the harmful displacement of $\mathrm{Ca}^{2+}$ by $\mathrm{Na}^{+}$from the cell membranes and intercellular pools (Lauchli, 1990). Adequate $\mathrm{Ca}^{2+}$ is necessary to maintain cell growth. Zhong and Lauchli (1988) reported that $150 \mathrm{~mm} \mathrm{NaCl}$ severely inhibits the incorporation of glucose into cellulose, an inhibition that is reversed by $10 \mathrm{~mm} \mathrm{Ca}^{2+}$ supplementation. However, in our experiments, supplemental $\mathrm{Ca}^{2+}$ 
Table 4. Influence of $\mathrm{NaCl}$ and $\mathrm{Ca}^{2+}$ treatments on growth characteristics of 'Tifblue' rabbiteye blueberry plants.

\begin{tabular}{|c|c|c|c|c|c|c|c|c|c|}
\hline \multirow{2}{*}{$\begin{array}{l}\text { Ion and } \\
\text { concn } \\
\text { (mM) }\end{array}$} & \multicolumn{2}{|c|}{ Fresh $w^{2}(\mathrm{~g})$} & \multirow{2}{*}{$\begin{array}{c}\text { Estimated } \\
\text { leaf } \\
\text { count }\end{array}$} & \multicolumn{3}{|c|}{ Dry wt (g) } & \multirow{2}{*}{$\begin{array}{c}\text { Leaf } \\
\text { fresh wt : } \\
\text { dry wt } \\
\text { ratio }\end{array}$} & \multirow{2}{*}{$\begin{array}{c}\text { Shoot : } \\
\text { root } \\
\text { ratio } \\
\end{array}$} & \multirow{2}{*}{$\begin{array}{l}\text { Avg } \\
\text { leaf } \\
\text { area } \\
\left(\mathrm{cm}^{2}\right) \\
\end{array}$} \\
\hline & Leaf & Stem & & Leaf & Stem & Root & & & \\
\hline \multicolumn{10}{|l|}{$\mathrm{Na}^{+}(\mathrm{NaCl})$} \\
\hline 0 & 87.9 & 56.8 & 409 & 28.6 & 22.4 & 16.7 & 3.1 & 3.1 & 10.0 \\
\hline 25 & 73.8 & 54.4 & 383 & 25.5 & 21.6 & 16.9 & 2.8 & 2.9 & 8.8 \\
\hline 100 & 29.2 & 29.0 & 223 & 10.4 & 13.2 & 9.3 & 2.7 & 2.6 & 5.9 \\
\hline \multicolumn{10}{|l|}{$\mathrm{Ca}^{2+}$} \\
\hline 0 & 65.7 & 48.4 & 348 & 22.7 & 20.2 & 14.9 & 2.8 & 2.8 & 8.0 \\
\hline 1 & 66.6 & 44.8 & 337 & 21.2 & 18.9 & 12.8 & 3.1 & 3.3 & 8.9 \\
\hline 3 & 62.7 & 46.4 & 365 & 21.6 & 17.8 & 14.5 & 2.8 & 2.7 & 7.5 \\
\hline 10 & 59.0 & 46.8 & 301 & 20.5 & 19.2 & 14.6 & 2.8 & 2.7 & 8.4 \\
\hline \multicolumn{10}{|l|}{ Source ${ }^{y}$} \\
\hline $\mathrm{Na}^{+}$ & 0.0001 & 0.0001 & 0.0001 & 0.0001 & 0.0001 & 0.0001 & 10.0001 & 0.0001 & 0.0001 \\
\hline $\mathrm{Ca}^{2+}$ & NS & NS & NS & NS & NS & NS & 0.0612 & 0.0658 & NS \\
\hline $\mathrm{Ca}^{2+} \times \mathrm{NaCl}$ & 0.0881 & NS & NS & NS & NS & NS & NS & NS & NS \\
\hline \multicolumn{10}{|l|}{ Contrast ${ }^{\mathbf{x}}$} \\
\hline Linear $\mathrm{Na}^{+}$ & 0.0001 & 0.0001 & 0.0001 & 0.0001 & 0.0001 & 0.0001 & 10.0001 & 0.0001 & 0.0001 \\
\hline
\end{tabular}

${ }^{2}$ All fresh and dry weight values are reported as grams per plant.

'Probability of a significant $\mathrm{F}$ value, NS = nonsignificant.

${ }^{x}$ Both linear and quadratic $\mathrm{Ca}^{2+}$ contrasts were nonsignificant.

Table 5. Influence of $\mathrm{NaCl}$ and $\mathrm{Ca}^{2+}$ treatments on growth characteristics of 'Sharpblue' southern highbush blueberry plants.

\begin{tabular}{|c|c|c|c|c|c|c|c|c|c|}
\hline \multirow{2}{*}{$\begin{array}{l}\text { Ion and } \\
\text { concn } \\
(\mathrm{mM})\end{array}$} & \multicolumn{2}{|c|}{ Fresh $w^{2}(g)$} & \multirow{2}{*}{$\begin{array}{c}\text { Estimated } \\
\text { leaf } \\
\text { count }\end{array}$} & \multicolumn{3}{|c|}{ Dry wt $(\mathrm{g})$} & \multirow{2}{*}{$\begin{array}{l}\text { Leaf } \\
\text { fresh wt } \\
\text { dry wt } \\
\text { ratio }\end{array}$} & \multirow{2}{*}{$\begin{array}{c}\text { Shoot : } \\
\text { root } \\
\text { ratio }\end{array}$} & \multirow{2}{*}{$\begin{array}{l}\text { Avg } \\
\text { leaf } \\
\text { area } \\
\left(\mathrm{cm}^{2}\right) \\
\end{array}$} \\
\hline & Leaf & Stem & & Leaf & Stem & Root & & & \\
\hline \multicolumn{10}{|l|}{$\mathrm{Na}^{+}(\mathrm{NaCl})$} \\
\hline 0 & 59.9 & 26.0 & 177 & 20.2 & 8.7 & 12.9 & 2.9 & 2.3 & 18.4 \\
\hline 25 & 41.4 & 19.0 & 124 & 12.9 & 6.8 & 8.4 & 3.2 & 2.5 & 16.6 \\
\hline 100 & 8.9 & 7.2 & 72 & 4.2 & 3.2 & 3.3 & 1.2 & 2.0 & 5.4 \\
\hline \multicolumn{10}{|l|}{$\mathrm{Ca}^{2+}$} \\
\hline 0 & 36.0 & 16.6 & 141 & 11.5 & 6.2 & 7.6 & 2.7 & 2.4 & 12.8 \\
\hline 10 & 35.5 & 17.4 & 124 & 12.7 & 6.1 & 8.4 & 2.1 & 2.1 & 13.7 \\
\hline \multicolumn{10}{|l|}{ Sourcey } \\
\hline $\mathrm{Na}^{+}$ & 0.0001 & 0.0002 & 0.0440 & 0.0001 & 0.0067 & 0.0004 & 0.0001 & NS & 0.0002 \\
\hline $\mathrm{Ca}^{2+}$ & NS & NS & NS & NS & NS & NS & 0.0779 & NS & NS \\
\hline \multicolumn{10}{|l|}{ Contrast } \\
\hline Linear $\mathrm{Na}+$ & 0.0001 & 0.0001 & 0.0556 & 0.0001 & 0.0022 & 0.0002 & 0.0001 & NS & 0.0001 \\
\hline
\end{tabular}

${ }^{2}$ All fresh and dry weight values are reported as grams per plant.

'Probability of a significant $\mathrm{F}$ value, NS $=$ nonsignificant. The $\mathrm{Ca}^{2+} \times \mathrm{Na}^{+}$interaction was nonsignificant.

could not ameliorate the detrimental effects of $100 \mathrm{mM} \mathrm{Na}^{+}$as $\mathrm{NaCl}$ on blueberry growth.

The inability of $\mathrm{Ca}^{2+}$ to limit $\mathrm{NaCl}$ salinity damage may be related to the specific ion effects of $\mathrm{NaCl}$ salinity. Since $\mathrm{SO}_{4}^{2-}$ is not known to be damaging to blueberries, the shoot growth depression caused by $\mathrm{Na}_{2} \mathrm{~S} \mathrm{O}_{4}$ salinity may be due chiefly to $\mathrm{Na}^{+}$, and the greater depression caused by $\mathrm{NaCl}$ salinity, relative to $\mathrm{Na}_{2} \mathrm{SO}_{4}$, may be due at last partially to the added effect of the $\mathrm{Cl}^{-}$. Therefore, a plausible explanation of the inability of $\mathrm{Ca}^{2+}$ treatments to offset $\mathrm{NaCl}$ salinity damage is that $\mathrm{Ca}^{2+}$ cannot restrict the entry of $\mathrm{Cl}^{-}$or overcome its effects in $\mathrm{Cl}^{-}$-sensitive species. In fact, Brown et al. (1953) proposed that $\mathrm{Ca}^{2+}$ facilitates $\mathrm{Cl}^{-}$uptake in various Prunus spp., all of which are sensitive to high levels of $\mathrm{Cl}^{-}$, but Ehlig (1965) did not find that $\mathrm{Ca}^{2+}$ enhanced $\mathrm{Cl}^{-}$uptake in raspberries (Rubus idaeus L.). This question remains to be investigated in blueberry.
Additionally, the higher $\mathrm{Ca}^{2+}$ treatments may have been detrimental to unsalinized blueberries because excessive $\mathrm{Ca}^{2+}$ has been shown to limit growth by reducing cell wall expansion in some species. Hansen and Munns (1988) found that for Leucaena leucocephala, high $\mathrm{CaSO}_{4}$ levels depressed growth of unsalinized plants. Eklund and Eliasson (1990) demonstrated that cellulose deposition in spruce [picea abies (L.) Karst.] was inhibited by high $\mathrm{Ca}^{2+}$. Calcium supplements decreased the plastic extensibility of soybean [Glycine max (L.) Merr.] hypocotyl cell walls (Virk and Cleland, 1988). Calcium may also directly inhibit cell wall growth by displacing $\mathrm{H}+$ from the Donnan Free Space near the cell wall, thus inhibiting enzymes responsible for wall loosening that have acidic pH optima (Cleland et al., 1990). Furthermore, high $\mathrm{Ca}^{2+}$ may adversely affect cell metabolism in calcifuge species, such as blueberries, which are efficient $\mathrm{Ca}^{2+}$ accumulators, as high $\mathrm{Ca}^{2+}$ disrupts metabolic processes in other species (Brauer et al., 1990). Calcium levels within the cytoplasm must remain 
low to avoid precipitation of inorganic phosphorus, competition with $\mathrm{Mg}^{2+}$ and inadvertent activation or inactivation of enzyme systems (Marschner, 1986).

In contrast to its ineffective protection from $\mathrm{NaCl}$ salinity, and possible detrimental effects on unsalinized plants, $\mathrm{Ca}^{2+}$ was often able to ameliorate the detrimental effects of $\mathrm{Na}^{+}$ as $\mathrm{Na}_{2} \mathrm{SO}_{4}$ on blueberry shoot growth. In 'Tifblue' plants this resulted mainly from greater leaf fresh and dry weight, probably because of greater leaf area and the emergence of new leaves on $\mathrm{Ca}^{2+}$-treated plants. Under $\mathrm{Na}_{2} \mathrm{SO}_{4}$ salinization $(25$ $\mathrm{mM} \mathrm{Na}$ ), 3 and $10 \mathrm{~mm} \mathrm{Ca}^{2+}$ appeared to be optimal for growth of blueberries. These treatments were equivalent to $\mathrm{Na}^{+}: \mathrm{Ca}^{2+}$ ratios of $8.3: 1$ and $2.5: 1$. While little work has been done using $\mathrm{Na}_{2} \mathrm{SO}_{4}$, other research indicates that growth of plants exposed to $\mathrm{NaCl}$ is least affected by salinity under similar $\mathrm{Na}^{+}: \mathrm{Ca}^{2+}$ ratios; growth of $\mathrm{NaCl}$-treated sour orange was optimum at a ratio of 8:1 (Zekri and Parsons, 1990), and dry weight of $\mathrm{NaCl}$-treated bean with a $\mathrm{Na}^{+}: \mathrm{Ca}^{2+}$ ratio of 16.7:1 almost equalled the dry weight of control plants (LaHaye and Epstein, 1971). With $50 \mathrm{mM} \mathrm{Na}_{2} \mathrm{SO}_{4}$, the optimum $\mathrm{Ca}^{2+}$ concentration was $1 \mathrm{~mm}$. This contrasts with barley, where Cramer et al. (1989) found that shoot growth of NaCl-stressed plants was optimal at $10 \mathrm{~mm} \mathrm{Ca}^{2+}$. A similar positive response to high $\mathrm{Ca}^{2+}$ for plants salinized with $\mathrm{NaCl}$ was previously reported with $L$. leucocephala (Hansen and Munns, 1988), sour orange (Zekri and Parsons, 1990), and bean (LaHaye and Epstein, 1971), but none of the above species are calcifuge.

Why might 'Tifblue' blueberry react differently than other species to high and low supplemental $\mathrm{Ca}^{2+}$ concentrations under high $\mathrm{Na}_{2} \mathrm{SO}_{4}$ salinity? At $\mathrm{Ca}^{2+}$ concentrations > $1 \mathrm{~mm}$, an ameliorative effect in relation to $\mathrm{Na}^{+}$may be offset by the detrimental effect of $\mathrm{Ca}^{2+}$ on the metabolism of the calcifuge blueberry. Such a harmful effect may be exacerbated because of the presence of high $\mathrm{Na}^{+}$. This relationship suggests that management of $\mathrm{Ca}^{2+}$ in blueberry plants exposed to salinity requires the maintenance of low but appreciable amounts of $\mathrm{Ca}^{2+}$ in the rooting zone.

The ameliorative effects of $\mathrm{Ca}^{2+}$ appear to be cultivar specific, since no single $\mathrm{Ca}^{2+}$ treatment led to significantly improved 'Brightwell' shoot growth at high $\mathrm{Na}^{+}$as $\mathrm{Na}_{2} \mathrm{~S} \mathrm{O}_{4}$ concentrations, and $\mathrm{Ca}^{2+}$ had no ameliorative effect on 'Sharpblue' growth. Thus, 'Brightwell' and 'Sharpblue' may be more sensitive to high concentrations of $\mathrm{Na}_{2} \mathrm{SO}_{4}$ than 'Tifblue', or, alternatively, the former cultivars may be more sensitive to excess $\mathrm{Ca}^{*}+$.

In conclusion, rabbiteye and southern highbush blueberries are sensitive to a high level $\left(100 \mathrm{mM} \mathrm{Na}^{+}\right)$of salinity, which causes severe depression of growth of shoots and roots, whereas there was much less effect at $25 \mathrm{~mm} \mathrm{Na}^{+}$. Root growth was depressed more than shoot growth, regardless of the $\mathrm{Na}^{+}$salt applied. Supplemental $\mathrm{Ca}^{2+}$ did not ameliorate $\mathrm{NaCl}$ salinity damage to shoots on any cultivar, possibly because of the inability of $\mathrm{Ca}^{2+}$ to counter the toxic effects of $\mathrm{Cl}^{-}$. This lack of effect suggests that blueberries are especially sensitive to $\mathrm{Cl}^{-}$. Under moderate $\mathrm{Na}_{2} \mathrm{SO}_{4}$ salinity treatment $\left(25 \mathrm{~mm} \mathrm{Na}{ }^{+}\right.$), supplemental $\mathrm{Ca}^{2+}(3$ or $10 \mathrm{~mm})$ successfully ameliorated salinity damage by improving leaf growth. Under high $\mathrm{Na}_{2} \mathrm{SO}_{4}$ salinity treatment $\left(100 \mathrm{mM} \mathrm{N} \mathrm{a}^{+}\right), 1 \mathrm{mM} \mathrm{Ca}^{2+}$ produced optimum leaf growth, possibly because application of higher concentrations of $\mathrm{Ca}^{2+}$ were detrimental to the metabolism of the calcifuge blueberry.

\section{Literature Cited}

Austin, M.E., T.P. Gaines, and R.E. Moss. 1986. Influence of soil $\mathrm{pH}$ on soil nutrients, leaf elements, and yield of young rabbiteye blueberries. HortScience 21:443-445.

Ballinger, W.E. 1962. Studies of sulfate and chloride ion effects upon 'Wolcott' blueberry growth and composition. Proc. Amer. Soc. Hort. Sci. 80:331-339.

Ballinger, W.E., A.L. Kenworthy, H.K. Bell, E.J. Benne, and S.T. Bass. 1958. Production in Michigan blueberry plantations in relation to nutrient-element content of the fruiting-shoot leaves and soil. Michigan Quart. Bul. 40896-905.

Bongi, G. and F. Loreto. 1989. Gas-exchange properties of salt-stressed olive (Olea europea L.) leaves. Plant Physiol. 90:1408-1416.

Brauer, M., D. Sanders, and M. Stitt. 1990. Regulation of photosynthetic sucrose synthesis: A role for calcium? Planta 182:236-243.

Brown, J.W., C.H. Wadleigh, and H.E. Hayward. 1953. Foliar analysis of stone fruit and almond trees on saline substrates. Proc. Amer. Soc. Hort. Sci. 61:49-54.

Cleland, R.E., S.S. Virk, D. Taylor, and T. Björkman. 1990. Calcium, cell walls and growth, p. 9-16. In: R.T. Leonard and P.K. Hepler (eds.). Calcium in plant growth and development. Amer. Soc. Plant Physiol. Symp. Ser. vol. 4. Amer. Soc. Plant Physiol., Rockville, Md.

Cramer, G.R., E. Epstein, and A. Läuchli. 1988. Kinetics of root elongation of maize in response to short-term exposure to $\mathrm{NaCl}$ and elevated calcium concentration. J. Expt. Bot. 39:1513-1522.

Cramer, G., E. Epstein, and A. Lluchli. 1989. Na-Ca interactions in barley seedlings: relationship to ion transport and growth. Plant Cell \& Environ. 12:551-558.

Cramer, G.R., J. Lynch, A. Lauchli, and E. Epstein. 1987. Influx of $\mathrm{Na}^{+}, \mathrm{K}^{+}$and $\mathrm{Ca}^{2+}$ into roots of salt-stressed cotton seedlings. Plant Physiol. 83:510-516.

Downton, W.J.S. 1977. Photosynthesis in salt-stressed grapevines. Austral. J. Plant Physiol. 4:183-192.

Ehlig, C.F. 1965. Salt tolerance of raspberry, boysenberry, and blackberry. Proc. Amer. Soc. Hort. Sci. 85:318-324.

Eklund, L. and L. Eliasson. 1990. Effects of calcium ion concentration on cell wall synthesis. J. Expt. Bot. 41:863-867.

Haby, V.A. and H.D. Pennington. 1988. Irrigation water source and quality, p. 2-1-2-13. In: M.L. Baker, K.D. Patten, E.W. Neuendorff, and C. Lyons (eds.). Texas blueberry handbook-Production and marketing. Texas Agr. Ext. Serv., Texas Agr. Expt. Sta. and Texas A\&M Univ., College Station.

Haby, V.A., K.D. Patten, D.L. Cawthon, B.B. Kresja, E.W. Neuendorff, J.V. Davis, and S.C. Peters. 1986. Response of containergrown rabbiteye blueberry plants to irrigation water quality and soil type. J. Amer. Soc. Hort. Sci. 111:332-337.

Hansen, E.H. and D.N. Munns. 1988. Effect of $\mathrm{CaSO}_{4}$ and $\mathrm{NaCl}$ on growth and nitrogen fixation of Leucaena leucocephala. Plant \& Soil 107:95-99.

Hope-Simpson, J.F. 1938. A chalk flora of the Lower Greensand; its uses in interpreting the calcicole habit. J. Ecol. 26:218-235.

LaHaye, P.A. and E. Epstein. 1969. Salt toleration by plants: Enhancement with calcium. Science 166:395-396.

LaHaye, P.A. and E. Epstein. 1971. Calcium and salt toleration by bean plants. Physiol. Plant. 25:213-218.

Lauchli, A. 1990. Calcium, salinity and the plasma membrane, p. 2635. In: R.T. Leonard and P.K. Hepler (eds.). Calcium in plant growth and development. Amer. Soc. Plant Physiol. Symp. Ser. vol. 4, Amer. Soc. Plant Physiol., Rockville, Md.

Maas, E.V. and C.M. Grieve. 1987. Sodium-induced calcium deficiency in salt-stressed corn. Plant Cell \& Environ. 10:559-564.

Manchanda, H.R. and S.K. Sharma. 1989. Tolerance of chloride and sulphate salinity in chickpea (Cicer arietinum). J. Agr. Sci., Cambridge 113:407-410.

Marschner, H. 1986. Mineral nutrition in higher plants. Academic, London.

Patten, K.D., E.W. Neuendorff, A.T. Leonard, and V.A. Haby. 1988. 
Mulch and irrigation placement effects on soil chemistry properties and rabbiteye blueberry plants irrigated with sodic water. J. Amer. Soc. Hort. Sci. 113:4-8.

Spiers, J.M. 1979. Calcium and nitrogen nutrition of 'Tifblue' rabbiteye blueberry in sand culture. HortScience 14:.523-525.

Spiers, J.M. 1983. Influence of N, K and Na-concentration on growth and leaf element content of 'Tifblue' rabbiteye blueberry. HortScience 18:223-224.

Texas Department of Health. 1990. Chemical analysis of public water systems. Stock no, 2-123, Texas Dept. Health, Austin.
Virk, S.S. and R.L. Cleland. 1988. Calcium and the mechanical properties of soybean hypocotyl cell walls: Possible role of calcium and protons in cell wall loosening. Planta 176:60-67.

Zekri, M. and L.R. Parsons. 1990. Calcium influences growth and leaf mineral concentrations of citrus under saline conditions. HortScience 25:784-786.

Zhong, H. and A. Lauchli. 1988. Incorporation of $\left[{ }^{14} \mathrm{C}\right]$ glucose into cell wall polysaccharides of cotton roots: Effects of $\mathrm{NaCl}$ and $\mathrm{CaCl}_{2}$ Plant Physiol. 88:511-514. 